\title{
HUBUNGAN POLA ASUH KELUARGA DENGAN KEKAMBUHAN PASIEN SKIZOFRENIA DI RSJ. HB. SA'ANIN PADANG TAHUN 2017
}

\author{
Diana Arianti ${ }^{1}$, Milya Novera ${ }^{2}$, Afrida Yani Rosa ${ }^{2}$ \\ ${ }^{1}$ STIKes Alifah, Padang 25000 \\ Email: dianaarianti84@gmail.com \\ ${ }^{2}$ Sekolah Tinggi Ilmu Keperawatan Alifah Padang \\ Email: stikes_alifah@yahoo.com \\ ${ }^{3}$ Sekolah Tinggi Ilmu Keperawatan Alifah Padang \\ Email: stikes_alifah@yahoo.com
}

\begin{abstract}
ABSTRAK
Skizofrenia merupakan gangguan mental yang paling berat dan kronik (psikotik) di antara sekian banyak gangguan mental yang telah diklasifikasikan. Pola asuh dalam keluarga sangat dibutuhkan dalam mengatasi hal ini. Pola asuh keluarga yang penuh kasih sayang dan pendidikan tentang nilai-nilai kehidupan, baik kesehatan sosial dan agama yang diberikan merupakan faktor yang kondusif untuk mempersiapkan anak menjadi pribadi dan anggota masyarakat yang sehat (Widodo, 2014). Penelitian ini bertujuan untuk menngidentifikasi hubungan Pola Asuh Keluarga dengan Kekambuhan pasien Skizofrenia di RSJ. HB. Sa'anin Padang Tahun 2017”.

Jenis penelitian ini analitik menggunakan desain cross sectional study. Penelitian dilakukan pada tanggal 03 - 18 Agustus 2017. Sampel keluarga pasien skizofrenia sebanyak 159 orang dengan teknik pengambilan sampel accidental sampling di poliklinik RSJ. Hb Saanin Padang. Hasil penelitian didapatkan 54.1\% pasien mengalami tingkat kekambuhan tinggi. $50,8 \%$ pasien mempunyai pola asuh orang tua tidak efektif. Ada hubungan antara pola asuh orang tua dengan tingkat kekambuhan penderita skizofrenia di Rumah Sakit Jiwa HB. Sa'anin Padang $(\mathrm{p}=0.007)$.

Disimpulkan bahwa ada hubungan pola asuh orang tua dengan tingkat kekambuhan penderita skizofrenia di Rumah Sakit Jiwa HB. Sa'anin Padang Tahun 2017. Peneliti menyarankan kepada petugas kesehatan rumah sakit untuk memberikan pendidikan kesehatan kepada keluarga tentang pola asuh yang baik yang harus diterapkan kepada pasien skizofrenia pasca dirawat sehingga bisa menekan tingkat kekambuhan pasien
\end{abstract}

Kata kunci : Pola asuh, Skizofrenia

\begin{abstract}
Schizophrenia is the most severe and chronic mental disorder (psychotic) among the many mental disorders that have been classified. Data from 33 mental hospitals (RSJ) that exist throughout Indonesia to say the number of people with severe mental disorders reached 2.5 million peoples. The Objective of study was to knows The Relation of Family Foster Pattern with Schizophrenia Recurrence at RSJ. of HB. Sa'anin of Padang in 2017.

Type of the research is analytical descriptive with cross-sectional approach. The research has been conducted at RSJ. of HB. Sa'anin of Padang. Data is collected on 03 - 09 August in 2017. The population in this study were the all families who accompany patients in RSJ. of HB. Sa'anin of Padang. Samples taken by accidental sampling of 61 peoples. Data analysis is done univariately and bivariately by using chi-square test..

Research findings showed that $54.1 \%$ the patient experiences a high recurrence rate. 50,8\% the patient has an ineffective parenting pattern. There is a relationship between parenting patterns with recurrence rates of schizophrenics in RSJ. of HB. Sa'anin of Padang ( $p=0.007)$.

It was concluded that there was a correlation between parenting parenting with the recurrence rate of schizophrenia in RSJ. of HB. Sa'anin of Padang in 2017. The researcher suggests to hospital health workers to provide family health education about good parenting that should be applied to post-treated schizophrenic patients so as to reduce the patient's recurrence rate
\end{abstract}

Keyword: Parenting, Schizophrenia. 


\section{PENDAHULUAN}

Menurut WHO (2014) menyatakan bahwa kesehatan jiwa adalah keadaan well-being dimana setiap individu menyadari potensinya, dapat mengatasi stress yang normal dalam kehidupan sehari-hari, dapat bekerja dengan produktif dan bermanfaat. Masyarakat menganggap gangguan jiwa merupakan aib bagi keluarga yang memiliki anggota keluarga yang mengalami gangguan jiwa. Berbagai upaya dilakukan keluarga untuk menyembunyikan atau mengasingkan orang gangguan jiwa dari pergaulan lingkungan (Jayadi, 2012).

Berdasarkan data dari World Health Organisasi (WHO) dalam Yosep (2014), ada sekitar 450 juta orang di dunia yang mengalami gangguan jiwa. Menurut Michard \& Chaterina (dalam Yosep, 2014), masalah kesehatan jiwa akan menjadi The global burden of disease. Berdasarkan data di Amerika Serikat : (1) Setiap tahun terdapat tiga ratus ribu pasien skizofrenia mengalami episode akut; (2) Prevalensi skizofrenia lebih tinggi dari penyakit Alzheimer, multipel skeleosis, pasien diabetes yang memakai insulin, dan penyakit otot (muscular dystrophy); (3) 20\%-50\% pasien skizofrenia melakukan percobaan bunuh diri, dan $10 \%$ di antaranya berhasil (mati bunuh diri); (4) angka kematian pasien skizofrenia 8 kali lebih tinggi dari angka kematian penduduk pada umumnya (Yosep, 2010).

Menurut Dirjen Bina Kesehatan Masyarakat (2014), mengatakan jumlah penderita gangguan jiwa di masyarakat sangat tinggi, yakni 1 dari 4 penduduk Indonesia menderita kelainan jiwa dari rasa cemas, depresi, stress, penggunaan obat, kenakalan remaja sampai schizophrenia. Salah satu gangguan jiwa terberat adalah schizophrenia.

Berdasarkan hasil penelitian dari Rudi Maslim dalam Mubarta (2011) prevalensi masalah kesehatan jiwa di Indonesia sebesar 6,55\%. Angka tersebut tergolong sedang dibandingkan dengan negara lainnya. Kasus gangguan jiwa di Indonesia pada tahun 2013 sebesar 7,7 \% dari seluruh penduduk Indonesia, dengan pembagian gangguan jiwa berat $1,7 \%$ dan gangguan mental emosional sebasar $6 \%$ dengan jumlah seluruh RT yang dianalisis adalah 294.959 terdiri dari 1.027.763 ART yang berasal dari semua umur.

Data dari 33 Rumah Sakit Jiwa (RSJ) yang ada di seluruh Indonesia menyebutkan hingga kini jumlah penderita gangguan jiwa berat mencapai 2,5 juta orang. Penderita gangguan jiwa berat dengan usia di atas 15 tahun di Indonesia mencapai $0,46 \%$. Hal ini berarti terdapat lebih dari 1 juta jiwa di Indonesia yang menderita gangguan jiwa berat. Hasil survei Riset Dasar Kesehatan (Riskesdas) tahun 2013 menunjukan prevalensi gangguan jiwa di Indonesia mencapai $14,3 \%$, pedesaan $18,2 \%$, perkotaan $10,7 \%$.
Skizofrenia merupakan gangguan mental yang paling berat dan kronik (psikotik) di antara sekian banyak gangguan mental yang telah diklasifikasikan. Saat ini diperkirakan sebanyak $12-12,5 \%$ penduduk mengalami gangguan ini (Martaniah, 2006). Dewasa ini, skizofrenia merupakan bahasan yang menarik perhatian pada konferensi tahunan "The American Psychiatric Association atau APA" di Miami, Florida, Amerika Serikat, Mei 1995. Angka pasien skizofrenia di Amerika Serikat cukup tinggi (lifetime prevalance rates) mencapai satu per seratus penduduk.

Pasien skizofrenia sering kali kurang diperhatikan dalam masyarakat pasien skizofrenia sering dianggap berbahaya padahal mereka juga pasien yang sangat membutuhkan perhatian dari dokter dan keluarga serta masyarakat. Mereka lebih sering disebut masyarakat sebagai orang gila. Stigma yang begitu melekat pada pasien gangguan skizofrenia adalah mereka berbahaya (Achjar, 2012).

Pada pasien skizofrenia yang telah dinyatakan sembuh dan dikembalikan lagi pada keluarga, sering kambuh lagi karena adanya stigma yang berkembang di masyarakat bahwa mereka tidak dapat sembuh, mereka dikucilkan, tidak diberi peran, dukungan sosial dan ejekan (Noorkasiani, 2009). Kekambuhan skizofrenia rata-rata ditandai dengan klien yang sudah sembuh dan dipulangkan ke lingkungan keluarga umumnya beberapa hari saja, minggu, atau bulan di rumah kembali dirawat dengan alasan perilaku pasien tidak diterima oleh keluarganya, klien selalu diawasi, dilarang keluar, selalu dicurigai, klien cenderung terisolisir dari pergaulannya dan cenderung menutup diri (Widodo, 2014).

Pola asuh dalam keluarga sangat dibutuhkan dalam mengatasi hal ini. Pola asuh keluarga yang penuh kasih sayang dan pendidikan tentang nilainilai kehidupan, baik kesehatan sosial dan agama yang diberikan merupakan faktor yang kondusif untuk mempersiapkan anak menjadi pribadi dan anggota masyarakat yang sehat (Widodo, 2014).

Penelitian yang telah dilakukan oleh Baumrind dalam Dariyo (2004), membagi pola asuh orang tua menjadi tiga yakni Otoriter, Permisif, dan Demokratis. Penelitian yang sudah diteliti menunjukkan pola asuh permisif (anak bebas dalam berbuat dan bertingkah laku) sebagai faktor predisposisi terjadinya skizofrenia. Dalam kenyataan, orang awam tidak mengetahui bahwa pola asuh yang ditanamkan oleh keluarga itu ternyata dapat nenyebabkan terjadinya skizofrenia, sehingga sering suatu keluarga memberikan pola asuh yang salah hingga akhirnya berdampak terjadinya skozofrenia ini.

Pola asuh yang dilakukan orang tua akan menjadikan anak belajar tentang banyak hal termasuk karakter. Hubungan orang tua-anak yang salah atau interaksi yang patogenik dalam keluarga sering merupakan sumber gangguan penyesuaian diri. Kadang-kadang orang tua berbuat terlalu banyak 
untuk anak dan tidak memberi kesempatan anak itu berkembang sendiri. Ada kalanya orang tua berbuat terlalu sedikit dan tidak merangsang anak itu atau tidak memberi bimbingan dan anjuran yang dibutuhkannya. Kadang-kadang mereka malahan mengajarkan anak itu pola-pola yang tidak sesuai, akan tetapi, pengaruh cara asuhan anak tergantung pada keadaan sosial secara keseluruhan dimana hal itu dilakukan. Oleh karena itu sumber penyebab gangguan jiwa salah satunya dari faktor sosio-budaya (sosiogenik), yaitu diantaranya pola mengasuh anak, kestabilan keluarga, tingkat ekonomi, perumahan, pengaruh rasial dan keagamaan, nilai-nilai, dan masalah minoritas (Yosep, 2014).

Masyarakat masih banyak yang tidak paham bagaimana idealnya menangani orang dengan gangguan jiwa. Beban yang ditimbulkan oleh gangguan jiwa ini sangatlah besar. Pasien skizofrenia bagi keluarganya merupakan beban yang sangat berat, namun pada umumnya keluarga tetap menunjukkan rasa tanggung jawab, dukungan, dan kasih sayang yang besar kepada pasien tersebut.

Berdasarkan data yang diperoleh dari RSJ. Prof. HB. Sa'anin Padang tahun 2016 penderita schizofrenia sebanyak 1177 orang yang terdiri dari pasien laki-laki sebanyak 954 dan perempuan sebanyak 223 orang, dan data pada tiga bulan terakhir dari bulan Desember 2016 - Februari 2017 sebanyak 319 orang. Berdasarkan survey awal yang telah peneliti lakukan di RSJ. Prof. HB. SA'anin Padang tahun 2017 didapatkan 6\% keluarga mengatakan sudah memberikan pola asuh kepada klien akan tetapi klien masih belum bisa beradaptasi dengan keluarga atau lingkungan 2\% keluarga diantaranya tidak memberikan kesempatan untuk berbicara yang diingin oleh anak, $4 \%$ orang tua tidak memberikan anaknya untuk berpendapat dan $4 \%$ keluarga mengatakan tidak memberikan pola asuh yang sesuai karena keluarga masih belum bisa menerima klien sehingga keluarga tidak memperhatikan klien dan keluarga sibuk dengan urusan mereka masing-masing sehingga keluarga melalaikan klien.

Penelitian yang telah dilakukan oleh St. Aisyah (2010), menyatakan bahwa kondisi keluarga yang cenderung tidak sehat dapat memunculkan gejala skizofrenia pada anggota keluarganya, terutama pada anak. Kondisi patologis di sini disebabkan oleh beberapa keadaan, seperti jalinan hubungan antara ibu dengan anak yang tidak baik, pola komunikasi keluarga yang tidak tepat, serta pola pengasuhan orang tua yang tidak sesuai. Berbagai keadaan tersebut akan menyebabkan perkembangan kepribadian anak menjadi tidak sehat.

Berdasarkan latar belakang diatas, penulis melakukan penelitian tentang "Hubungan Pola Asuh Keluarga dengan Kekambuhan pasien Skizofrenia di RSJ. HB. Sa’anin Padang Tahun 2017’.
Jenis penelitian ini adalah kuantitatif dengan pendekatan desain cross sectional study. Penelitian ini telah di lakukan di Poliklinik RSJ HB. Sa'anin Padang. Pengumpulan data di lakukan pada tanggal 03 - 09 Agustus 2017. Populasi penelitian ini para orang tua atau saudara yang mengetahui pola asuh yang diberikan pada pasien. Teknik pengambilan sampel yang digunakan dalam penelitian ini adalah accidental sampling sebanyak 61 orang. Pengumpulan data menggunakan instrumen. Pengolahan data melalui analisa data secara univariat dan bivariat yang dianalisis dengan statistic uji squaare.

\section{HASIL}

\section{a. Analisa Univariat}

1. Tingkat Kekambuhan

Distribusi frekuensi tingkat kekambuhan dikategorikan atas dua yaitu tinggi dan rendah dengan hasil sebagai berikut :

Tabel 1. Distribusi Frekuensi Responden Menurut Tingkat Kekambuhan Penderita Skizofrenia di Rumah Sakit Jiwa Prof. HB. Sa'anin Padang

\begin{tabular}{clcc}
\hline No & Tingkat Kekambuhan & f & \% \\
\hline 1 & Tinggi & 33 & 54,1 \\
2 & Rendah & 28 & 45,9 \\
\hline & Jumlah & $\mathbf{6 1}$ & $\mathbf{1 0 0 , 0}$ \\
\hline
\end{tabular}

Berdasarkan pada tabel 1. dapat dilihat bahwa lebih dari separoh responden mengalami tingkat kekambuhan tinggi yaitu sebanyak 33 orang $(54,1 \%)$ di Rumah Sakit Jiwa Prof. HB. Sa'anin Padang.

\section{Pola Asuh Orang Tua}

Distribusi frekuensi pola asuh orang tua dikategorikan atas dua yaitu tidak efektif dan efektif dengan hasil sebagai berikut :

Tabel 2. Distribusi Frekuensi Responden Menurut Pola Asuh Orang Tua Penderita Skizofrenia di RSJ Prof. HB. Sa'anin Padang

\begin{tabular}{clcc}
\hline No & Pola Asuh Orang Tua & F & \% \\
\hline 1 & Tidak Efektif & 31 & 50,8 \\
2 & Efektif & 30 & 49,2 \\
\hline & Jumlah & $\mathbf{6 1}$ & $\mathbf{1 0 0 , 0}$ \\
\hline
\end{tabular}

Berdasarkan pada tabel 2. dapat dilihat bahwa lebih dari separoh responden mempunyai pola asuh orang tua tidak efektif yaitu sebanyak 31 orang $(50,8 \%)$ di Rumah Sakit Jiwa Prof. HB. Sa'anin Padang.

\section{b. Analisa Bivariat}

Hasil hubungan pola asuh orang tua dengan tingkat kekambuhan pada penderita Skizofrenia dapat dilihat sebagai berikut :

\section{II.METODA PENELITIAN}


Tabel 3 Hubungan Pola Asuh Orang Tua dengan Tingkat Kekambuhan Pada Penderita Skizofrenia di RSJ Prof. HB. Sa'anin Padang

\begin{tabular}{ccccccccc}
\hline \multirow{2}{*}{ No } & \multirow{2}{*}{$\begin{array}{c}\text { Pola Asuh } \\
\text { Orang Tua }\end{array}$} & \multicolumn{3}{c}{ Tingkat Kekambuhan } & \multirow{2}{*}{ Jumlah } \\
\cline { 3 - 6 } & & \multicolumn{2}{c}{ Tinggi } & \multicolumn{2}{c}{ Rendah } & & \\
\cline { 3 - 7 } & Tidak Efektif & 22 & 71,0 & 9 & 29,0 & 31 & 100 \\
2 & Efektif & 11 & 36,7 & 19 & 63,3 & 30 & 100 \\
2 & Jumlah & $\mathbf{3 3}$ & $\mathbf{5 4 , 1}$ & $\mathbf{2 8}$ & $\mathbf{4 5 , 9}$ & $\mathbf{5 5}$ & $\mathbf{1 0 0}$ \\
\hline
\end{tabular}

Tabel 3. menjelaskan bahwa proporsi responden yang mengalami tingkat kekambuhan tinggi lebih banyak terdapat pada responden yang mempunyai pola asuh orang tua tidak efektif yaitu sebanyak 22 orang $(71.0 \%)$ dibandingkan dengan pola asuh orang tua efektif yaitu sebanyak 11 orang $(36,7 \%)$. Hasil uji statistik didapatkan nilai $\mathrm{p}=0,007(\mathrm{p}<0,05)$ yang berarti ada hubungan antara pola asuh orang tua dengan tingkat kekambuhan penderita skizofrenia di Rumah Sakit Jiwa Prof. HB. Sa'anin Padang.

\section{PEMBAHASAN}

\section{A. Analisis Univariat}

\section{Tingkat Kekambuhan}

Hasil penelitian menunjukkan bahwa lebih dari separoh responden mengalami tingkat kekambuhan tinggi yaitu sebanyak 33 orang $(54,1 \%)$ di Rumah Sakit Jiwa Prof. HB. Sa'anin Padang. Hasil penelitian ini sejalan dengan penelitian yang dilakukan oleh Fauziah (2015) tentang hubungan pengetahuan dan sikap keluarga dengan kekambuhan klien skizofrenia di RSJ Prof. HB Saanin Padang Tahun 2015. Hasil penelitian menunjukkan bahwa $52,3 \%$ pasien mengalami kekambuhan tinggi.

Skizofrenia merupakan gangguan pikiran, emosi menumpuk, dan hubungan dengan dunia luar, lingkungan tergannggu. Gangguan pikiran dan menumpuknya emosi sebagai gejala utama dari skizofrenia, dan adanya halusinasi atau delusi (waham) merupakan gejala sekunder atau hambatan (Lumbantobing, 2007).

Kekambuhan adalah suatu keadaan dimana timbulnya kembali suatu penyakit yang sudah sembuh dan disebabkan oleh berbagai macam faktor penyebab. Pencegahan kekambuhan adalah mencegah terjadinya peristiwa timbulnya kembali gejala-gejala yang sebelumnya sudah memperoleh kemajuan (Andri, 2008).

Kekambuhan gangguan jiwa psikotik adalah munculnya kembali gejala-gejala psikotik yang nyata. Angka kekambuhan secara positif hubungan dengan beberapa kali masuk rumah sakit, lamanya dan perjalanan penyakit. Penderita-penderita yang kambuh biasanya sebelum keluar dari rumah sakit mempunyai karakteristik hiperaktif, tidak mau minum obat dan memiliki sedikit keterampilan sosial. (Porkony dkk, dalam Akbar, 2008)

Berdasarkan penelitian ditemukan cukup banyaknya pasien skizofrenia yang mengalami kekambuhan dengan kategori tinggi di RSJ Prof. HB Saanin Padang Tahun 2015. Hal ini menujukkan masih kurang baiknya perawatan yang didapatkan klien di rumah. Menurut Agus (2001) penyebab kekambuhan klien skizofrenia adalah faktor psikososial yaitu pengaruh lingkungan keluarga maupun sosial. Menurut Keliat (2007) beberapa faktor yang mempengaruhi terjadinya kekambuhan pada klien gangguan jiwa antara lain faktor klien, faktor dokter, faktor penanggungjawab klien (case manager) dan faktor keluarga. Keluarga dengan ekspresi emosi yang tinggi seperti bermusuhan, mengkritik, tidak ramah, banyak menekan dan menyalahkan, menyebabkan 57\% klien kembali kambuh dalam waktu 9 bulan.

Masih kurang baiknya perawatan keluarga dapat disebabkan karena faktor karakteristik responden. Dimana berdasarkan umur didapatkan data bahwa paling banyak adalah keluarga berumur dewasa tua sebanyak 72,1\% (44 orang) dan dewasa tua sebanyak 27,9\% (17 orang). Dengan umur dewasa muda ini dapat menyebabkan keluarga belum terlalu matang pola berpikir mereka dalam perawatan pasien skizofrenia sehingga dapat menyebabkan terjadinya kekambuhan kembali pada pasien.

Berdasarkan pekerjaan didapatkan bahwa paling banyak adalah keluarga berprofesi IRT sebanyak 50,8\% atau sebanyak 31 orang, selanjutnya adalah petani sebanyak 10 orang $(16,4 \%)$ dan pekerjaan responden paling sedikit adalah guru sebanyak 2 orang (3,3\%). Dengan profesi sebagai IRT ini apat menunjukkan keluarga menyebabkan kurang informasi tentang perawatan pasien skizofrenia yang baik karena kurangnya informasi yang mereka dapatkan tentang perawatan pasien skizorenia yang baik sehingga menyebabkan kurang baiknya perawatan keluarga sehingga dapat memicu terjadinya kekambuhan kembali pada pasien.

Berdasarkan pendidikan didapatkan paling banyak keluarga adalah tamatan SLTA yaitu sebanyak 25 orang $(41.0 \%)$. Dengan pendidikan ini menunjukkan masih rendahnya tingkat pendidikan keluarga sehingga akan mempengaruhi terhadap kurangnya pemahaman keluarga tentang cara merawat pasien skizofrenia secara baik sehingga perawatan keluarga akan kurang baik sehingga 
akan menyebabkan tingginya tingkat kekambuhan pasien.

Kondisi harus segera ditanggapi karena jika hal ini dibiarkan maka tingkat pemulihan kembali pada klien akan susah dilakukan. Dalam proses penyembuhan pada klien skizofrenia harus dilakukan secara holistik dan melibatkan anggota keluarga. Keluarga sangat penting untuk ikut berpartisipasi dalam proses penyembuhan karena keluarga merupakan pendukung utama dalam merawat klien (Keliat, 2007).

Keluarga perlu membantu klien bersosialisasi kembali, menciptakan kondisi lingkungan supportif, menghargai klien secara pribadi, membantu pemecahan masalah klien (Gilang, 2001). Keluarga menemani klien melakukan perawatan lanjutan pada puskemas atau rumah sakit terdekat (Keliat, 2007). Selain itu keluarga juga harus menumbuhkan sikap mandiri dalam diri klien (Handayani, 2008).

Menurut Simanjuntak dan Daulay (2006), mengatakan bahwa kekambuhan pada pasien skizofrenia akan menyebabkan beberapa permasalahan diantaranya stress, kecemasan pada keluarga, sesama keluarga saling menyalahkan, kesulitan pemahaman (kurangnya pengetahuan keluarga) dalam menerima sakit yang diderita oleh anggota keluarganya yang mengalami skizofrenia.

Asumsi peneliti terhadap penelitian ini adalah ditemukan cukup banyaknya klien yang mengalamsi kekambuhan dengan kategori tingkat tinggi. Hal ini terlihat terjadinya kekambuhan kembali pada pasien kurang dari 1 tahun setelah mereka dirawat. Terjadinya kekambuhan kembali pada pasien ini dapat disebabkan karena kurang baiknya perawatan yang dilakukan keluarga terhadap pasien sehingga pasien merasa tidak diterima dari lingkungan sehingga memacu terjadi stressor pada pasien sehingga memicu terjadinya kekambuhan kembali pada pasien.

\section{Pola Asuh Orang Tua}

Hasil penelitian menunjukkan bahwa lebih dari separoh responden mempunyai pola asuh orang tua tidak efektif yaitu sebanyak 31 orang (50,8\%) di Rumah Sakit Jiwa Prof. HB. Sa'anin Padang. Sejalan dengan hasil penelitian Lazuardi (2015), menunjukkan bahwa $64,3 \%$ responden memiliki pola asuh negatif .

Pola asuh adalah segala aspek yang berkaitan dengan pemeliharaan, perawatan, dukungan, dan bantuan sehingga orang tetap berdiri dan menjalani hidupnya secara sehat (Fajri, 2009). Ditambahkan oleh Yosep (2014) bahwa pola asuh yang dilakukan orang tua akan menjadikan anak belajar tentang banyak hal termasuk karakter.
Terlihat pada penelitian bahwa cukup banyak pasien yang memiliki pola asuh orang tua tidak efektif. Hal ini terlihat dari hasil analisis kuesioner, dimana pada pola asuh otoriter didapatkan data bahwa $93 \%$ responden menyatakan bahwa orang tua tidak memberikan kesempatan pada anaknya untuk menjelaskan kesalahan yang telah ia lakukan, $72 \%$ responden menyatakan bahwa orang tua memarahi anak bahkan memukul anak adalah hal yang wajar dilakukan orang tua, $69 \%$ responden menyatakan bahwa orang tua selalu memaksakan kehendak dirinya, karena mereka lebih mengetahui mana yang terbaik untuk anak tanpa merundingkannya terlebih dahulu dan $51 \%$ responden menyatakan bahwa no. 9 .

Pada pola asuh demokratis didapatkan data bahwa $54 \%$ responden menyatakan bahwa orang tua mengarahkan anak ketempat yang ia inginkan, walau orang tua tidak menyukainya, $21 \%$ responden menyatakan bahwa orang tua tidak merundingkan segala hal yang terjadi kepada anak dan keluarga , $18 \%$ responden menyatakan bahwa salah satu tugas orangtua adalah memberikan jadwal harian anak untuk belajar dan $11 \%$ responden menyatakan bahwa sebagai orangtua kita tidak selalu harus mengingatkan anak setiap waktu, untuk belajar .

Pada pola asuh permisif didapatkan data bahwa $64 \%$ responden menyatakan bahwa orang selalu menuruti kemauan anak meski orang tua tidak menyukainya merupakan salah satu cara oran tua menunjukan kasih sayang, $61 \%$ responden menyatakan bahwa orang tua tidak berhak mengatur anak , 59\% responden menyatakan bahwa orang tua membiarkan anak bebas memilih apa yang ia ingin lakukan dan kerjakan, $51 \%$ responden menyatakan bahwa sebagai orangtua kita tidak perlu membatasi pergaulan anak dan $51 \%$ responden menyatakan bahwa dengan sendirinya anak akan memahami mana yang baik dan yang buruk tanpa harus diberitahu orangtua.

Pada pola asuh laissez faire didapatkan data bahwa 14,75 \% respoden menyatakan bahwa orang tua yang menggunakan gaya laissez faire tidak menginginkan seluruh anaknya berpartisipasi tanpa memaksa atau menuntut kewenangan yang dimiliki dan $3.28 \%$ responden menyatakan bahwa orang tua tidak selalu memilih terbuka kepada anak dengan sedikit campur tangan orang tua agar kebebasan yang terkendali.

Menurut Syam (2015), pola asuh yang tidak efektif diterapkan orang tua terkadang dampaknya bagi anak bukannya baik tapi buruk. Pola asuh yang tidak efektif tentu menyebabkan anak menjadi tidak kreatif atau jadi selalu tergantung pada orang lain. Sehingga perlu berhati-hati dalam menerapkan pola asuh. 
Perlu diingat bahwa pola asuh sangat menentukan pertumbuhan anak, baik dalam potensi sosial, psikomotorik, dan kemampuan efektifnya.

Beberapa penelitian yang telah dilakukan bahwa pola asuh orang tua berpengaruh terhadap kepribadian seseorang. Anak yang diasuh dengan pola asuh permisif dan otoriter memiliki harga diri yang lebih rendah dari pada anak yang diasuh dengan pola asuh demokratis (Laksmlasari, 1994). Anak dengan harga diri rendah dan kondisi mental yang lemah maka akan lebih memiliki resiko terhadapa kejadian gangguan jiwa. Pola asuh otoriter juga merupakan faktor resiko terjadinya cemas berpisah. Sedangkan pola asuh demokratis bukan merupakan faktor resiko dari ketiga gangguan tersebut (Rutuwene, 1996).

Asumsi peneliti tentang hasil penelitian adalah ditemukan bahawa cukup banyak pasien skizofrenia banyak memiliki pola asuh orang tua yang tidak efektif. Padahal pola asuh ini sangat dibutuhkan pasien, orang tua banyak yang suka memaksakan kehendak kepada anak mereka, hal ini dapat berdampak tidak baik pada anak. Dalam hal ini perlu adanya program edukasi oleh petugas kesehatan pada orang tua atau keluarga yang menemani pasien tentang pola asuh yang efektif pada pasien sehingga keluarga dapat menerapkan pola asuh yang efektif terhadap pasien

\section{B. Analisa Bivariat}

\section{Hubungan Pola Asuh Orang Tua dengan Tingkat Kekambuhan pada Penderita Skizofrenia}

Hasil penelitian menunjukkan bahwa proporsi responden yang mengalami tingkat kekambuhan tinggi lebih banyak terdapat pada responden yang mempunyai pola asuh orang tua tidak efektif yaitu sebanyak 22 orang $(71.0 \%)$ dibandingkan dengan pola asuh orang tua efektif yaitu sebanyak 11 orang $(36,7 \%)$. Hasil uji statistik didapatkan nilai $\mathrm{p}=0,007(\mathrm{p}<0,05)$ yang berarti ada hubungan antara pola asuh keluarga dengan tingkat kekambuhan penderita skizofrenia di Rumah Sakit Jiwa Prof. HB. Sa'anin Padang.

Hasil penelitian ini sejalan dengan penelitian Pebrianti (2009) menyatakan bahwa terdapat hubungan antara pola asuh otoriter dengan kejadian skizofrenia dengan nilai $\rho=$ 0,241 dan $\rho=0,047(\mathrm{p}<\alpha=0,05)$. Juga sejalan dengan hasil penelitian Handayani (2013), menemukan adanya hubungan pola asuh dan ekspresi emosi dengan kekambuhan pasien skizofrenia di RSJ Menur Surabaya $(\mathrm{p}=0,020)$. Hasil penelitian ini juga didukung oleh penelitian Lazuardi (2015), menyatakan bahwa adanya hubungan yang signifikan antara pola asuh orangtua dengan kejadian skizofrenia pada keluarga Desa Banaran Galur Kulon Progo.

Terbukti pada penelitan bahwa ada hubungan pola asuh keluarga dengan tingkat kekambuhan penderita skizofrenia di Rumah Sakit Jiwa Prof. HB. Sa'anin Padang. Hal ini dapat disebabkan karena pola asuh yang tidak efektif dapat menyebabkan pasien merasa dikucilkan, tidak diterima dan merasa selalu dicurigai sehingga pasien mengalami kekambuhan. Sesuai dengan pendapat Widodo (2014) bahwa pasien skizofrenia bagi keluarganya merupakan beban yang sangat berat, namun pada umumnya keluarga tetap menunjukkan rasa tanggung jawab, dukungan, dan kasih sayang yang besar kepada pasien tersebut. Kekambuhan skizofrenia rata-rata ditandai dengan klien yang sudah sembuh dan dipulangkan ke lingkungan keluarga umumnya beberapa hari saja, minggu, atau bulan di rumah kembali dirawat dengan alasan perilaku pasien tidak diterima oleh keluarganya, klien selalu diawasi, dilarang keluar, selalu dicurigai, klien cenderung terisolisir dari pergaulannya dan cenderung menutup diri.

Keluarga berperan penting dalam pola asuh yang diberikan kepada anak, pola asuh akan menentukan pembentukan perkembangan anak dimasa yang akan datang. Hal ini sesuai dengan pernyataan Gunarsa (2008), keluarga memiliki fungsi dasar seperti memenuhi kebutuhan fisik, memberi kasih sayang, rasa nyaman, rasa memiliki dan menyiapkan peran dewasa individu kedalam masyarakat. Fungsi dasar keluarga diwujudkan dalam bentuk interaksi orangtua dengan anak. Menurut Schafer (dalam Handayani, 2013) mengungkapkan bahwa anak-anak yang di telantarkan oleh orangtuanya baik secara fisik maupun mental dapat meningkatkan risiko munculnya gangguan jiwa.

Asumsi peneliti terhadap penelitian ini adalah terbukti bawa pola asuh kelaurga akan mempengaruhi tingkat kekambuhan pasien skizofrenia, dimana jika pola asuh keluarga tidak efektif akan menyebabkan tingkat kekambuhan yang lebih tinggi dibandingkan dengan tingkat kekambuhan yang efektif. Dimana dengan adanya pola asuh yang efektif maka pasien akan merasa nyaman, aman dan merasa diperhatikan sehingga dapat mengurangi tingkat kekambuhan pada pasien. Dengan demikian untuk mencegah terjadinya tingkat kekambuhan pada pasien skizofernia maka perlu adanya penerapan pola asuh yang efektif oleh terhadap pasien.

\section{KESIMPULAN}


Berdasarkan dari hasil penelitian, analisa dan pembahasan mengenai hubungan pola asuh keluarga dengan kekambuhan skizofrenia di RSJ. HB. Sa'anin Padang tahun 2017, maka dapat disimpulkan sebagai berikut: Lebih dari separoh pasien mengalami tingkat kekambuhan tinggi yaitu sebanyak 33 orang $(54,1 \%)$, Lebih dari separoh pasien mempunyai pola asuh orang tua tidak efektif yaitu sebanyak 31 orang $(50,8 \%)$, Ada hubungan antara pola asuh orang tua dengan tingkat kekambuhan penderita skizofrenia di Rumah Sakit Jiwa HB. Sa'anin Padang $(\mathrm{p}=0,007)$.

Diharapkan kepada petugas kesehatan rumah sakit untuk memberikan pendidikan kesehatan kepada keluarga tentang pola asuh yang baik yang harus diterapkan kepada pasien skizofrenia pasca dirawat sehingga bisa menekan tingkat kekambuhan pasien

\section{DAFTAR PUSTAKA}

Achjar, Komang AH. 2012. Aplikasi Praktis Asuhan Keperawatan Keluarga. Jakarta : CV Sagung Seto.

Agus, D. 2001. Faktor-faktor yang Mempengaruhi Pasien Skizofrenia di RSJP Jakarta dan Sanatorium Dharmawangsa dalam Pemilihan Jalur Pelayanan Kesehatan Pertama Kali dan Keterlambatan Kontak ke Fasilitas Pelayanan Kesehatan Jiwa. Dipublikasikan dalam http. www.google.php.htm.

Ahmad, Abu dan Supriyono,Widodo. 2014. Psikologi Belajar. Jakarta : PT Rineka Cipta.

Aisyah, Siti, dkk. 2010. Perkembangan dan Konsep Dasar Pengembangan Anak Usia Dini. Jakarta: Universitas Terbuka.

Akbar. 2008. Kekambuhan Klien Skizofrenia. Diakses dalam http://wirnursing.blogspot.com/2009/07/kekambuhan. html

Alwisol. 2007. Psikologi Kepribadian. UMM Press. Malang.

Andri, 2008. Kongres Nasional Skizofrenia V Closing The Treatment Gap For Schizophrenia

Arif, I. S. 2006. Skizofrenia: Memahami Dinamika Keluarga Pasien. Bandung: Rafika Aditama.

Arikunto, S. 2012. Prosedur Penelitian Suatu Pendekatan Praktik. Edisi Revisi VI. Jakarta : Rineka Cipta.

Boyer, C. D. dan J. C. Shannon. 2013. Carbohydrates of the Kernel. Di dalam: White, P. J. dan L. A. Johnson (eds.). Corn: Chemistry and Technology, 2nd edition. American Association of Cereal Chemistry Inc., St. Paul, Minnesota, USA.

Budiman, A, dkk. 2009. Penelitian Model Pengembangan Bodily-Kinestetik Intelegece
Sebagai Upaya Peningkatan Kompetensi Teknik Gerak Dalam Mata Kuliah Tari Lenyepan. Hibah Penelitian DIPA UPI.

Dariyo, Agoes. 2004. Psikologi Perkembangan Dewasa Muda. Jakarta: Grasindo.

Dirjen Bina Kesehatan Masyarakat. 2014. Profil Kesehatan Masyarakat Tahun 2013. Jakarta : Dirjen Bina Kesehatan Masyarakat.

Djamarah, Syaiful Bahri. 2014. Pola Asuh Orang Tua dan Komunikasi dalam Keluarga : Upaya Membangun Citra Membentuk Pribadi Anak. Jakarta, Rineka Cipta

Fajri dan Senja. 2009. Kamus Besar Bahasa Indonesia. Difa Publiser: Jakarta.

Fauziah. 2015. Hubungan Pengetahuan Dan Sikap Keluarga Dengan Kekambuhan Klien Skizofrenia di RSJ Prof. HB Saanin Padang Tahun 2015. Skripsi S1 Keperawatan STIKES Amanah padang.

Gilang, 2001. Pengendalian Terhadap Kekambuhan Klien Skizofrenia. Diakses dalam digilib.unimus.ac.id

Handayani, 2008. Kekambuhan Pada Klien Skizofrenia. Diakses dalam http://wirnursing.blogspot.com/2009/07/kekambuhan.h tml

Jayadi, F. 2012. Tepis Persepsi Salah Soal Sakit Jiwa,

http://suaramerdeka.com/v1/index.php/read/ cetak/2012/11/13/205337. Diakses tanggal 23 Januari 2017.

Kaplan, H.I., Sadock, B.J., and Grebb, J.A., 2010. Sinopsis Psikiatri : Ilmu Pengetahuan Perilaku Psikiatri Klinis. Jilid Dua. Editor : Dr. I. Made Wiguna S. Jakarta : Bina Rupa Aksara

Keliat, BA. 2007. Peran Serta Keluarga Dalam Perawatan Klien Gangguan Jiwa. EGC. Jakarta

Lumbantobing, SM. 2007. Neurogeriatri. Jakarta : Balai Penerbit FKUI. p. 111-122

Maramis, F.W. 2009. Ilmu Kedokteran Jiwa. Airlangga University Press : Surabaya

Martaniah, SM. 2006. Psikologi Abnormal dan Psikopatologi. Yogyakarta. Andi.

Maslim. R., 2002. Gejala Depresi, Diagnosa Gangguan Jiwa Rujukan Ringkas Dari PPDGJ-III. Jakarta : Bagian Ilmu Kedokteran Jiwa FK-Unika Atmajaya, 5865 
Mubarta, AF, dkk. 2011. Gambaran Distibusi Penderita Gangguan Jiwa di Wilayah Banjarmasin dan Banjarbaru. Tesis. http

//ejournal.unlam.ac.id/index.php/bk/article/d ownload/679/635 diunduh pada tanggal 23 Januari 2017.

Noorkasiani. 2009. Sosiologi Keperawatan. EGC : Jakarta

Notoadmodjo, S. 2012. Metodologi Penelitian Kesehatan. Rineka Cipta : Jakarta

Riset Kesehatan Dasar (Rikesdas). 2013. Badan Penelitian dan Pengembangan Kesehatan Republik Indonesia. Jakarta.

Sadock BJ, Sadock VA. Kaplan \& Sadock's. 2015. Synopsis of Psychiatry. Behavior Sciences/Clinical Psychiatry. 10th 2. ed. Lippincott Williams \& Wilkins, p.527-30.

Stuart GW, Sundeen SJ. 2007. Buku Saku Keperawatan Jiwa. Edisi 5 : Jakarta : EGCSugiyono, 2008
Sugiyono. 2011. Metode Penelitian Kuantitatif, Kualitatif, dan $R \& D$. Bandung : Alfabeta

Tsang, A.H.K., Chung, K.K.K., 2008. Oxidative and nitrosative stress in Parkinson's disease. Biochimica et Biophysica Acta. 643-650

WHO. 2014. Cancer. http://www.who.Int/media centre/factsheets/fs297/en/. Diakses Pada 23 Januari 2017.

Yosep, Iyus. 2010. Keperawatan Jiwa. Bandung: Refika Aditama

dan Titin Sutini. 2014. Buku Ajar Keperawatan Jiwa. Bandung: Refika Aditama

Yusniyah. 2008. Hubungan Pola Asuh Orang Tua dengan Prestasi Belajar Siswa MTS Al-Falah Jakarta Timur, Skripsi S1 Pendidikan Islam. Universitas Islam Negeri Syarif Hidayatullah Jakarta 